\title{
THE SOCIAL AND THE ECONOMIC IN SOCIAL BUSINESS: PROPOSITION OF A CONCEPTUAL MODEL
}

\section{O SOCIAL E O ECONÔMICO EM NEGÓCIOS SOCIAIS: PROPOSIÇÃO DE UM MODELO CONCEITUAL}

\author{
Aline dos Santos Barbosa ${ }^{1}$ \\ Edmilson Alves Moraes ${ }^{2}$ \\ Marcello Romani-Dias ${ }^{3}$
}

\begin{abstract}
This study seeks to analyze how social and economic goals can be balanced in social businesses with the construction of a conceptual model. Through a qualitative approach, proposing a conceptual model based on foundations that characterize the social and economic aspects of social businesses. To teste this model, a data collection instrument was also developed and applied in social businesses. The main finding was that the social businesses analyzed in this study have difficulty balancing their social and economic goals, and tend to concentrate more on one in detriment of the other. As a theoretical contribution, this study makes a contribution to the field by organizing criteria for analyzing this type of enterprise and as a basis for constructing social business measurement scales. As an empirical contribution, this article helps managers in terms of self-evaluation and also to understand how other social businesses address their social and economic goals.
\end{abstract}

Keywords: Social Business. Social Enterprises. Business with Social Impact.

\footnotetext{
${ }^{1}$ Bacharel em Comunicação Social com Habilitação em Publicidade e Propaganda, pela Universidade de Santo AmaroUNISA, Pós-graduação em Comunicação, Mercado e TI pela Fundação Instituto de Administração-FIA, Mestrado em Administração pelo Centro Universitário da FEI, Doutoranda em Administração de Empresas da Fundação Getúlio VargasEAESP-FGV, Professora da Universidade Ibirapuera, Professora da Universidade Ibirapuera, Brasil. Contato: aline8barbosa@gmail.com

${ }^{2}$ Bacharel em Engenharia Mecânica pelo Instituto de Educação Superior Santa Cecília, Mestrado em Administração de Empresas pela Fundação Getulio Vargas - SP, Doutorado em Administração de Empresas pela Fundação Getulio Vargas SP, Professor Adjunto I do Centro Universitário da FEI, Brasil. Contato: edmilson@ fei.edu.br

${ }^{3}$ Bacharel em Administração pela Escola Superior de Propaganda e Marketing, com especialização em Customer Relationship Management-ESPM, Especialização em Governança nos Negócios com foco em Direito, Economia e Gestão pela Fundação Instituto de Administração-FIA, Mestrado em Administração no Centro Universitário da FEI, Doutorando em Administração de Empresas da Fundação Getúlio Vargas-EAESP-FGV, Professor de Pós-graduação da Fundação Instituto de Administração-FIA, Brasil. Contato: mromdias@ hotmail.com
} 


\section{Resumo}

Este estudo buscou analisar como Negócios Sociais podem equilibrar objetivos sociais e econômicos com a construção de um modelo conceitual. Por meio de uma abordagem qualitativa e a proposição de um modelo conceitual baseado em fundamentos que caracterizam os aspectos sociais e econômicos de Negócios Sociais. Para testar este modelo, um questionário foi desenvolvido e aplicado em Negócios Sociais. Como principal descoberta destaca-se que os Negócios Sociais analisados demonstraram dificuldades em equilibrar seus objetivos sociais e econômicos e tendem a se concentrar mais em um objetivo em detrimento do outro. Como contribuição teórica, este estudo contribui para o campo ao organizar critérios para analisar esse tipo de negócio e, também como base para a construção de escalas de mensuração de Negócios Sociais. Como contribuição empírica, este trabalho ajuda gestores em termos de autoavaliação e também na compreensão de como outros Negócios Sociais lidam com seus objetivos sociais e econômicos.

Palavras-chave: Negócios Sociais. Empresas sociais. Negócios com impacto social.

\section{INTRODUCTION}

Social businesses are enterprises that combine economic objectives and social goals (BATTILANA; SENGUL; PACHE, 2015; DOHERTY; HAUGH; LYON, 2014). This business model employs a wide range of strategies to solve problems in society, with widespread examples, including the Grameen Bank (Bangladesh), Aashtha Hospital (India), Banco Pérola (Brazil) and Dr. Consulta (Brazil). In the case of the Grameen Bank and Banco Pérola, the social mission is to increase the income of a segment of the population. The mission of Aashtha Hospital and Dr. Consulta is to provide healthcare services to people in need in the regions where these institutions operate. These four enterprises also have characteristics of commercial businesses, as they aim to make a profit, but differ in how they distribute dividends between partners and shareholders, and do not aim to maximize profits (SMITH; GONIN; BESHAROV, 2013).

Two theoretical approaches stand out when it comes to defining this theme. The first is that of Yunus, Moingeon and Lehmann-Ortega (2010), who claim that the main objective of social businesses is to create a social impact, and that all the profit should be reinvested in the business and used to ease the burden of poverty, shunning the idea of individual wealth and striving for social and economic equality for all people. The second approach is that of the EMES (Emergence des Entrerprises Sociales en Europe) European Research Network, which understands social businesses as organizations that explicitly aim to benefit the community. However, they can also distribute profits, albeit with limits imposed on the financial gains of investors (DEFOURNY; NYSSENS, 2008; DEFOURNY; NYSSENS, 2010).

Given the viewpoints of these authors, it is clear that this kind of business needs to balance profits and social goals. However, there is the risk of leaning more towards social orientation, placing less emphasis on market practices, or prioritizing the maximization of profits, which would have a negative effect on social needs (GRASSL, 2012; SMITH; GONIN; BESHAROV, 2013).

Therefore, this article proposes a seven-point conceptual model to analyze the balance of social and economic goals in Brazilian social businesses. 
Based on qualitative research, the article seeks to analyze how social and economic goals can be balanced in social businesses with the construction of a conceptual model. The data were collected through document analysis and a semi-structured questionnaire, seeking to determine the balance of the seven points proposed in the conceptual model. In this sense, the study discusses the inherent importance of social businesses balancing their social and economic goals.

\section{LITERATURE REVIEW}

Inequality between social and environmental issues is a driving force in the growth of social businesses. This type of enterprise has existed for many years, but a consensus has yet to be reached regarding its concept and definition. The number of studies on the theme has grown over the years (DEES, 1998; MAIR; MARTÍ, 2006; SMITH; GONIN; BESHAROV, 2013, BARKI et al., 2015).

Social businesses combine the social goals of not-for-profit organizations with the generation of financial resources of traditional businesses, as shown in Table 1. While not-forprofit organizations exclusively aim to provide a social service, with donations as their source of income, traditional businesses seek to maximize profits for their partners and shareholders and are financially self-sustaining (YUNUS; MOINGEON; LEHMANN-ORTEGA, 2010).

Table I: Not-for-profit organizations, social businesses and traditional businesses

\begin{tabular}{c|c|c|c|}
\cline { 2 - 3 } & $\begin{array}{c}\text { Not-for-profit } \\
\text { organizations }\end{array}$ & Social Business & Traditional Business \\
\hline Objective & $\begin{array}{c}\text { Social profit } \\
\text { maximization }\end{array}$ & $\begin{array}{c}\text { Social profit } \\
\text { maximization }\end{array}$ & Financial profit \\
maximization
\end{tabular}

Note. Adapted by Yunus, Moingeon and Lehmann-Ortega (2010, p. 310).

Profit generation in social businesses is one of the typical characteristics of traditional businesses, requiring the stable and continuous production of goods and services and depending on the use of production factors, such as labor and credit. Owners of this type of business are expected to take significant economic risks in their activities (BORZAGA; DEPEDRI; GALERA, 2012).

According to Yunus, Moingeon and Lehmann-Ortega (2010), all the profit generated by the business should be reinvested to advance and improve the social side of the company, and if there is an investor to help the company initiate its activities, he should only be paid the amount invested and no other dividends as a result of the transaction. However, from the viewpoint of Defourny and Nyssens (2008), the partners and investors in this type of venture can receive part of the profits, but should not seek to maximize them in detriment of the social side of the business. 
Consequently, unlike traditional businesses, social businesses do not seek to maximize profits. They seek a return as a way of expanding their actions rather than generating wealth for the partners and shareholders (YUNUS; MOINGEON; LEHMANN-ORTEGA, 2010; DEFOURNY; NYSSENS, 2008; DEFOURNY; NYSSENS, 2010).

Moreover, approaches can differ from one geographical region to another, in an attempt to conceptualize and define social business, with viewpoints influenced by local cultures and realities. These regions include the United States, emerging countries and the European continent.

According to the American view, for instance, social businesses can take a number of organizational forms, ranging from initiatives involving corporate social responsibility or the marketing of large companies, to institutions created exclusively to generate social value (COMINI; ASSAD; FISCHER, 2012).

Young (2009, p. 35) sought to systematize these distinct identities for social businesses in the United States:

1. A hybrid: an organization with the dual aim of earning money for its stakeholders and addressing stated social goals;

2. A hybrid project: an organizational activity intended to make money to help fulfil the mission or social goals of the organization.

The predominant trend in Europe is to define social businesses as organizations that aim to benefit the community. These organizations, from this perspective, are the initiative of a group of citizens and limits are imposed on the earnings of investors. This group values the independence of the business and accepts the economic risks related to socio-economic activities (COMINI; ASSAD; FISCHER, 2012).

According to Travaglini, Bandini and Mancinone (2008), the characteristics of social businesses are as follows: (i) orientation to business - they are directly involved in manufacturing products and providing services on the market; (ii) orientation to social causes - they have clearly stated social or environmental causes, such as job creation and training, and their profits are reinvested to achieve their social goals; (iii) social ownership - they are autonomous organizations and the ownership structure and governance are based on the direct participation of groups of stakeholders, i.e., employees, users, customers, local community and social investors, or managers or directors that control the company with the intention of serving a vast group of stakeholders. Shares can be distributed among interested parties or they can be used to benefit the community, but their purpose is always to promote the economic and social integration of people who require assistance.

Thus, in the European view, in addition to a social purpose, organizations should attribute ownership rights and power of control to investors and interested parties, along with an open and participatory management model (GALERA; BORZAGA, 2009).

In emerging countries such as Brazil, the term inclusive business is used more than social business. This means that in some of these countries, enterprises with a social focus are intrinsically involved in fighting poverty over time by creating jobs and opportunities for people in a low income bracket.

In this sense, it could be said that inclusive businesses aim to create employment opportunities and income for people with little or no mobility on the job market, people with disabilities, providing them with a "decent standard of work" and enabling them to be selfsustaining. In other words, they will have a job that will generate profit for companies (COMINI; ASSAD; FISCHER, 2012).

Although these viewpoints differ, they share the idea of using this business model for a financially sustainable purpose and to make a social impact (YOUNG, 2007; DEFOURNY; 
NYSSENS, 2008; YUNUS; MOINGEON; LEHMANN-ORTEGA, 2010). These organizations are diverse, with many ideas and characterizations, as shown in Table 2:

Table II: Concepts of Social Businesses

\begin{tabular}{|c|c|c|c|}
\hline & $\begin{array}{c}\text { EUROPEAN } \\
\text { PERSPECTIVE }\end{array}$ & $\begin{array}{c}\text { AMERICAN } \\
\text { PERSPECTIVE }\end{array}$ & $\begin{array}{c}\text { EMERGING } \\
\text { PERSPECTIVE }\end{array}$ \\
\hline DEFINITION & $\begin{array}{l}\text { Organizations guided by } \\
\text { social company goals. }\end{array}$ & $\begin{array}{l}\text { Enterprising any market } \\
\text { activity that generates } \\
\text { social impact through } \\
\text { business activities. }\end{array}$ & $\begin{array}{l}\text { Organizations or } \\
\text { companies that } \\
\text { generate social change } \\
\text { through the stock } \\
\text { market. }\end{array}$ \\
\hline $\begin{array}{l}\text { CENTRAL } \\
\text { PROPOSAL }\end{array}$ & $\begin{array}{l}\text { To offer services originally } \\
\text { in the public sphere at a } \\
\text { low cost and generating } \\
\text { employment opportunities } \\
\text { for unemployed or } \\
\text { marginalized populations. }\end{array}$ & $\begin{array}{l}\text { To provide access to } \\
\text { benefits and services } \\
\text { previously only available to } \\
\text { the most privileged classes. }\end{array}$ & $\begin{array}{l}\text { Poverty reduction } \\
\text { initiatives that } \\
\text { generate positive and } \\
\text { effective social } \\
\text { impacts, especially in } \\
\text { the long term. }\end{array}$ \\
\hline SCALE & Not relevant & Extremely Relevant & Desirable \\
\hline PROFIT & $\begin{array}{l}\text { Reinvestment of profits in } \\
\text { the organization to generate } \\
\text { growth and increase social } \\
\text { impact. }\end{array}$ & $\begin{array}{l}\text { The distribution of } \\
\text { dividends is part of the } \\
\text { market logic. }\end{array}$ & $\begin{array}{l}\text { Asian Vision: profits } \\
\text { must be reinvested in } \\
\text { the business. } \\
\text { Latin American view: } \\
\text { distribution of profits. }\end{array}$ \\
\hline $\begin{array}{l}\text { GOVERNANCE } \\
\text { MODEL }\end{array}$ & $\begin{array}{l}\text { Several participants in } \\
\text { decision making. }\end{array}$ & $\begin{array}{l}\text { Centralization in decision } \\
\text { making; yet there are } \\
\text { business partners and the } \\
\text { idea of co-creation is } \\
\text { growing. }\end{array}$ & $\begin{array}{l}\text { Asian: Collaborative } \\
\text { and beneficiary } \\
\text { participation model. } \\
\text { Latin American: the } \\
\text { participatory and } \\
\text { centralized models are } \\
\text { accepted. }\end{array}$ \\
\hline $\begin{array}{c}\text { IMPACT } \\
\text { MEASUREMENT }\end{array}$ & Focus on the social impact. & Focus on the social impact. & $\begin{array}{l}\text { Focus on the social } \\
\text { impact. }\end{array}$ \\
\hline
\end{tabular}

Note. Adapted by Comini, Barki and Aguiar (2012, p. 394).

Table 2 shows that the American view of social businesses emphasizes the market logic, while the European perspective stresses the collective nature of social businesses. In emerging countries, the concept partly combines the American and European notions, but highlights the importance of including marginalized and neglected groups.

\section{Methodology}

\subsection{Proposal of a Conceptual Model and Data Collection Instrument}

The present study aims to analyze how social and economic goals can be balanced in social businesses with the construction of a conceptual model, using a qualitative approach, analyzing the literature and proposing a seven-point conceptual model. This model seeks to reconcile the social and economic goals of this type of enterprise. 
The seven points were based on the principles proposed by Yunus, Moingeon and Lehmann-Ortega (2010), who is responsible for the increasing popularity of this type of venture, and the work of Defourny and Nyssens (2008), responsible for defining the concept of the EMES.

From the definitions available in the literature on social businesses and the criteria proposed by Yunus, Moingeon and Lehmann-Ortega (2010). and Defourny and Nyssens (2008), the seven points regarding social and economic aspects for analyzing social businesses are shown in Figure 1.

Figure I: Conceptual Model for Analyzing Social Businesses

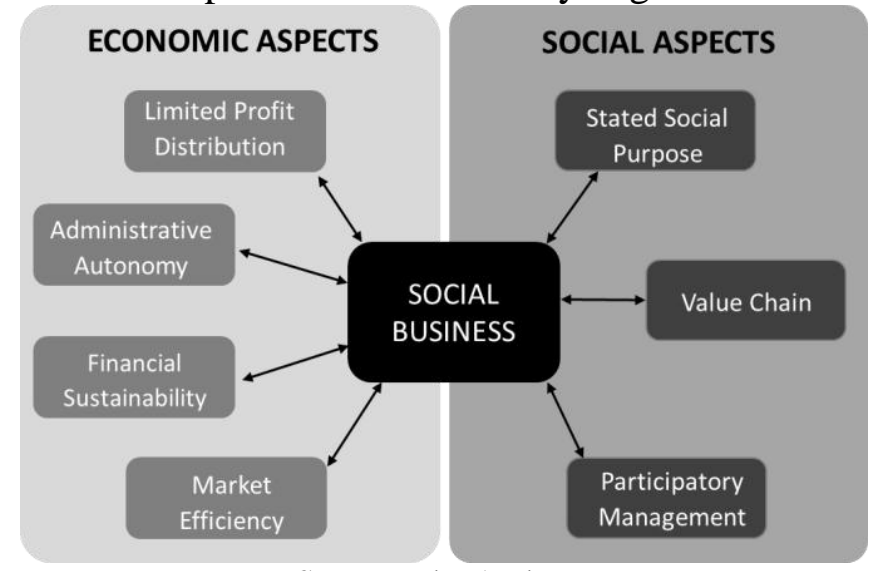

Source: The Authors.

\subsubsection{Stated Social Purpose}

A social business must have a social goal to benefit the community. This social goal might address issues such as education, healthcare, housing, leisure, quality of life and inclusion of minorities, such as women, African descendants, the elderly and people with special needs. In other words, the main purpose of a social business cannot be to maximize profit, but rather a social goal that benefits the community (DEFOURNY;BORZAGA, 2001; KERLIN, 2006; SHAW; CARTER, 2007; DEFOURNY; NYSSENS, 2008; TRAVAGLINI; BANDINI; MANCINONE, 2008; YUNUS; MOINGEON; LEHMANN-ORTEGA, 2010; BORZAGA; DEPEDRI; GALERA, 2012; COMINI; ASSAD; FISCHER, 2012).

\subsubsection{Value Chain}

According to Porter (1985), a value chain is a set of organizational activities that delivers value to stakeholders, including employees, customers, suppliers and the local community during the production, sale and final distribution of its products. This concern is an essential part of the daily life of a social business, and is not limited only to achieving its social goal (PORTER, 1985; DEFOURNY; BORZAGA, 2001; DEFOURNY; NYSSENS, 2008; YUNUS; MOINGEON; LEHMANN-ORTEGA, 2010; COMINI; ASSAD; FISCHER, 2012).

\subsubsection{Administrative Autonomy}

Social businesses must be created and managed by an individual or group of people. This type of enterprise can receive public investments or investments from private companies 
to begin its operations, for specific actions or a certain period of time, but cannot depend on these investments for its financial survival; nor can it be subject only to enacting decisions made by third parties. It is important for the enterprise to have a high degree of business autonomy (DEFOURNY; BORZAGA, 2001; BORZAGA; DEFOURNY, 2004; DEFOURNY; NYSSENS, 2008; YUNUS; MOINGEON; LEHMANN-ORTEGA, 2010; FISCHER; COMINI, 2012).

\subsubsection{Limited Profit Distribution}

The distribution of profits is a point on which the different definitions of social businesses diverge. According to authors like Yunus, Moingeon and Lehmann-Ortega (2010), all profit must be reinvested in the business and the investors should be paid only what they have invested, with no profit. However, authors such as Defourny and Nyssens (2008) allow for the distribution of profits, but not in such a way that the business should seek to maximize them. The primary concern of a social business should be with human dimensions, not profit. Part of the net revenues must be reinvested in the business with a view to social advances and improvements in the community (DEFOURNY; BORZAGA, 2001; BORZAGA; DEFOURNY, 2004; KERLIN, 2006; SHAW; CARTER, 2007; DEFOURNY; NYSSENS, 2008).

\subsubsection{Financial Sustainability}

For a social business to continue in the market and achieve its social goal, it is important for it to be financially healthy, have control over its costs and balance its expenditure and profits. Otherwise, this business runs the risk of having to close its doors and cease providing services to the community through its social and commercial operations. A social business cannot depend on donations, unlike non-profit-organizations or government programs, and their revenues have to cover their costs (DEFOURNY; BORZAGA, 2001; BORZAGA; DEFOURNY, 2004; DEFOURNY; NYSSENS, 2008; YUNUS; MOINGEON; LEHMANN-ORTEGA, 2010).

\subsubsection{Market Efficiency}

Social businesses combine the best features of traditional businesses, such as dynamism and efficiency, with the best of the political and economic sector, such as awareness and solutions to social problems. They participate in the production and sale of goods and services (with the sales generating shared value). In this sense, Porter (2011) claims that it is not only economic needs that define the market, but that companies should also consider social needs. When addressing these needs, a business does not increase its costs because these needs can generate new technologies, methods, operations and managerial approaches, resulting in increased productivity and expanding markets (DEFOURNY; BORZAGA, 2001; PRAHALAD, 2005; KERLIN, 2006; DEFOURNY; NYSSENS, 2008; YUNUS; MOINGEON; LEHMANN-ORTEGA, 2010; TRAVAGLINI; BANDINI; MANCINONE, 2008; PORTER, 2011).

\subsubsection{Participatory Management}

In social businesses, decisions are not only made by partners, shareholders or investors. Other stakeholders are heard and consulted in company planning. Decision-making 
is the responsibility of the partners, shareholders and investors based on these opinions, because social businesses must be participatory and involve the different parties affected by their activities (DEFOURNY; BORZAGA, 2001; DEFOURNY; NYSSENS, 2008; GALERA; BORZAGA, 2009; YUNUS; MOINGEON; LEHMANN-ORTEGA, 2010; COMINI; ASSAD; FISCHER, 2012).

The seven points in the proposed conceptual model are directly related to social business, as this type of business needs to balance all of these factors to be considered as such.

Ideally, social businesses should not concentrate on one point in detriment of another. In other words, they need to balance achieving their social goals with the relationship involved in their value chain, which includes employees, customers, the local community and suppliers. They also need to balance these points with participatory management involving their stakeholders.

Furthermore, social businesses have to balance their administrative autonomy and financial sustainability, without being subordinate to the decisions or aid of third parties to make decisions and ensure survival. Through the sale of goods and services, these enterprises must show market efficiency to create value. The profits generated by their activities should be distributed in a limited way.

\subsection{Data Collection Instrument}

For the data collection, a self-administered survey was used. According to Cooper and Schindler (2016), this method uses questionnaires that do not require the assistance of interviewers to be completed.

A data collection instrument was developed, made up of seven fundamental points: Stated Social Goal, Value Chain, Administrative Autonomy, Limited Profit Distribution, Financial Sustainability, Market Efficiency and Participatory Management, in addition to two blocks to characterize the company and the respondent. The instrument uses closed and openended questions, a semantic differential scale and a Likert scale.

Of the 64 questions, the questionnaire has 15 closed question, 12 open-ended, 22 using a semantic differential scale and 15 with a Likert scale. The latter is a 5-point scale, ranging from "I totally disagree" to "I totally agree", requiring the respondent to affirm to what extent he agrees with each statement in question.

Regarding the semantic differential scale, five points were also used, ranging from "never" to "always", requiring the respondent to indicate how frequently each statement is applicable. Furthermore, the closed questions had three categories of response ("yes", "no" and "I do not know"). The instrument has twelve open-ended questions intended to gather more detailed responses on some of the processes involved in the social businesses.

The enterprises chosen to teste the questionnaire and the conceptual model were identified in an academic survey conducted by the Social Business study group of the FEI University Center and the portfolio of the Artemísia business accelerator. This not-for-profit organization is a pioneer in the dissemination and promotion of social impact businesses in Brazil.

Thus, information on the study was sent through customer service centers and forwarded by e-mail and on social media, and a link was posted, allowing seven different companies to access the questionnaire developed using a tool on Google Docs, during the first semester of 2016. At the end, seven managers answered the questionnaire. 
In addition to the questionnaire, document research was conducted by consulting websites of the companies in question. Data were obtained from company documents regarding their mission, vision and values, which will be explained in the section that discusses the findings of the study.

\section{Discussion}

The social businesses focus on the environment, information technology and communication, education and information technology, tourism, project consultancy, information technology in health, food and land settlement.

Documentary research on the mission of the firms on their websites, social networks and digital publications identified the following missions: Respondent 3: "to promote experiences and cultural enrichment for people and deliver sustainable solutions to create income and self-esteem for community organizations and associations"; Respondent 1: "to provide social and environment consultancy to organizations working on development in the Amazon"; Respondent 5: "innovation to create technology services to improve accessibility to and availability of medical services and reduce the cost of communications in medical assistance"; Respondent 2: "to improve elementary and high-school education in Brazil by developing and selling innovative solutions in education"; Respondent 7: "to pacify and improve the quality of life in communities living in precarious settlements in Brazil and around the world".

Only two companies highlighted their vision as well as their mission, and only one published its values. Respondent 5 claimed that its vision was "to be a place where the public, health professionals and organizations could collaborate to achieve more personal, cheaper and quality healthcare for all". The vision of Respondent 7 was "to be an agent that multiplies sustainable actions, promoting social and environmental change worldwide". Regarding values, Respondent 7 declared that its values included "Ethics, transparency, respect, commitment, sustainability and teamwork".

Regarding the results obtained through responses to the points proposed in the model, the firms showed difficulty in balancing their social and economic goals, and are a long way from achieving the ideal results, as shown in Figure 2: 


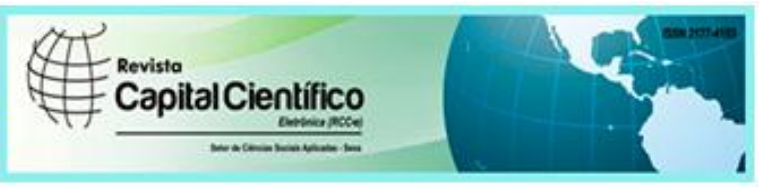

Figure II. Social Business Radar Chart

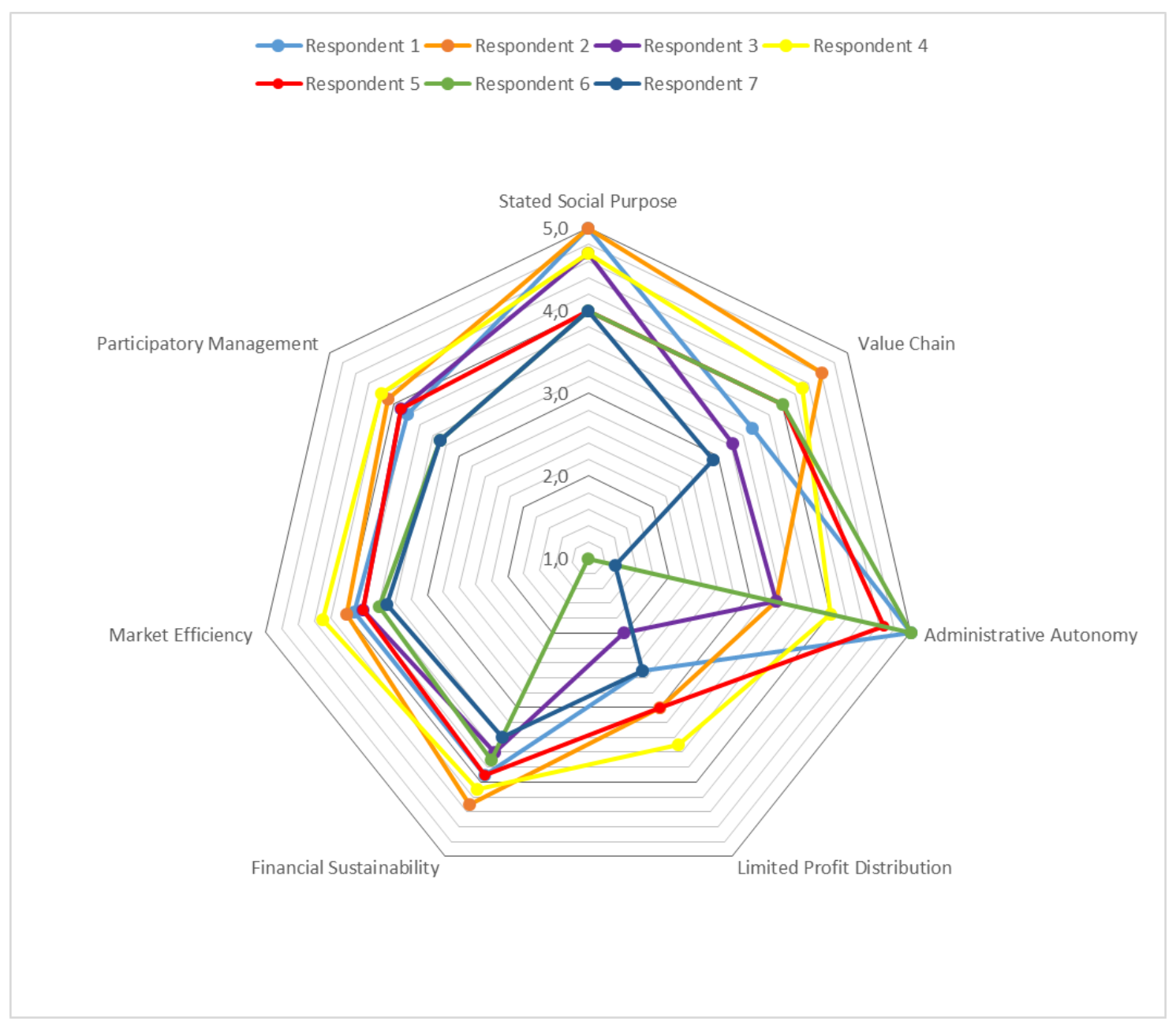

Source: The Authors.

The following social goals were declared in the questionnaires: Respondent 2: "to create the best learning experience for children aged 3 to 11, using innovative solutions focusing on the quality of the material, methodology and teacher training"; Respondent 3: "to aid local development, focusing on the tourism production chain"; Respondent 5: "to train people, professionals and organizations with collaborative tools to help improve the availability of and access to healthcare services"; Respondent 6: "to promote the production and sale of organic food, helping organic farmers and pacifying and improving the quality of life in the community".

Thus, in keeping with the social business criteria of Yunus, Moingeon and LehmannOrtega (2010), the respondents are involved in causes of education, health, access to technology and the environment, in addition to fighting poverty by helping local organic farmers and helping communities to improve their quality of life.

According to the respondents, over 35,000 people from many walks of life benefit from the missions, including: Respondent 2: "students, parents, teachers and pre-school managers and managers involved in the early years of high-school teaching, including both state and private schools"; Respondent 5: "citizens and healthcare professionals"; Respondent 1: "third-sector companies whose mission is related to the sustainable use of forests, research 
companies and cosmetic and drinks manufacturers"; Respondent 3: "public authorities, communities and NGOs"; Respondent 6: "family farmers, associations and cooperatives"; Respondent 7: "communities that live in precarious settlements (illegally occupied land)".

Furthermore, issues concerning research on the social requirements of the community to define the social goal and the partnerships formed for this purpose, the evaluation of results, the frequent attempts to gauge the needs of the local community and satisfy them, and the involvement of collaborators in these actions or social projects scored higher than 4 on a scale of 1 to 5 . In other words, the social businesses are in agreement on these aspects, which appear frequently on their agendas.

According to the responses in the questionnaires regarding Value Chain, the social businesses interact with the local community more frequently than with their customers and suppliers. This may be due to concern over fulfilling the social mission.

With regard to Autonomous Administration, some of the social businesses had a high degree of autonomy in decision-making. They are not subordinate to other companies and rarely receive investments for their financial survival. However, others showed a low level of autonomy and one respondent claimed that the company was rarely responsible for its decision-making.

Some of the social businesses frequently receive investments for social projects. This could be a sign that they do not have their own funds for actions that ae not directly related to their social goal, or that they have a strong articulation that allows them to work constantly in partnership with other companies.

Regarding Limited Profit Distribution, Respondents 1, 2, 5, 6 and 7 appear to comply with the vision of Yunus, Moingeon and Lehmann-Ortega (2010), and do not allow the distribution of profits among partners and shareholders. However, when asked about what happens to the profits, Respondents 2 and 6 claimed that they are still in the pre-revenue stage, i.e., the company has yet to turn a profit and, consequently, they are unable to say whether they will distribute it in the future.

Respondents 1, 4 and 7 claimed that the priority for profits is always, or often, to reinvest them in the business, but they are rarely or never earmarked for projects other than those related to the social goal of the company.

Respondent 1, in answer to an open-ended question on the allocation of profits, declared that it was distributed "as in the case of www.floraup.org". A study of this address showed that it is a participatory website, integrated with Google Maps and freely accessible. Using a digital map, it presents agro-extractive species and information on suppliers. In answer to an open-ended question on investment in other social projects, Respondent 1 replied that it does not invest in anything other than the company's mission. In other words, to this respondent, investment means reinvesting in the company to achieve its social goal, which is "starting in 2016, to organize information on the main commercial species from the Amazon and make them more accessible through research for the strategic purposes of innovation and projects to supply forest products".

In answer to an open-ended question on the allocation of profits, Respondent 4 declared, "The company reinvests its profit in the professionalization and growth of the business by taking development projects to communities". As for investments in other social actions, he stated that "There is occasional support for events and projects run by partners".

Respondent 7 replied to an open-ended question on the allocation of profits by declaring that "Money is allocated to residents' associations to be invested in projects that benefit the communities structurally and socially". He also declared that they "never invest" in other social projects. However, an analysis of his reply hints that they invest in projects that benefit the community and are aligned with the social goal of "pacifying and improving the 
quality of life of communities in precarious settlements in Brazil and around the world". Furthermore, this social business declared that its values were "to be an agent that multiplies sustainable actions, promoting social and environmental change worldwide".

Therefore, it is likely that this company understands that investments in the community are related to reinvestment in the company itself and does not invest in other projects only when they are not related to the social goals of the company.

Respondent 5 declared that the priority when allocating the profits is to reinvest in the company. This investment is made by "Increasing access (reducing costs and increasing distribution)", in alignment with the social goal, which is "innovation to create technology services to improve accessibility to and availability of medical services and reduce the cost of communications in medical assistance". Regarding investment in other social projects, this company stated that this never happens because "there is no profit". Moreover, the company claims that it does not distribute profit to partners and shareholders, possibly explaining why it declares there is no profit to invest in other social actions.

In general, the social businesses in the study rarely earmark part of their profits for other social actions beyond those mentioned in their social goals. This may be a positive aspect, if it means that the companies concentrate most or all of their profits in investments in achieving their social goals. However, it could mean that these companies allocate a considerable part of their profits to partners and shareholders, considering that they were asked about part of their profits and not all of them.

Concerning Financial Sustainability, when it comes to knowledge of the costs involved in the businesses, monitoring cash flow and budgetary planning, the companies agreed and stated that they conduct these processes frequently. In general, the companies claim that they rarely or only occasionally need to capture resources, i.e., borrow money to pay their expenses. This reinforces the earlier responses on their financial management.

Regarding cash reserves, the companies claim that they rarely have sufficient reserves for unexpected situations and have to manage unforeseen expenses. In other words, they appear to work with a very tight margins and may need to capture resources more frequently to handle situations for which they have not made plans.

When it comes to Market Efficiency, when asked about the positive results of improvements in managerial practices, the scores were poorer than the other items on this point. This may be a sign that the adjustments made are not efficient enough or that the companies are not analyzing the results and consequently, are unable to perceive any improvements. The questions on improvement in managerial practice and improvements in performance of products/services and processes had similar results, showing that the companies do not appear to be acting on these points frequently.

According to different authors, social businesses have a participatory nature that involves all parties affected by their activities. Thus, in this type of business, the stakeholders are expected to be involved, heard and consulted when it comes to company planning (DEFOURNY; BORZAGA, 2001; DEFOURNY; NYSSENS, 2008; GALERA; BORZAGA, 2009; YUNUS; MOINGEON; LEHMANN-ORTEGA, 2010; COMINI; ASSAD; FISCHER, 2012).

In terms of Participatory Management, the companies frequently talk and interact with to their customers, consumers and employees. This closer relationship may be due to their involvement with the companies' social goals.

Nevertheless, involvement with the local community had poorer results and may show that the companies are focused on their activities and are not so close to the community. This results is questionable, as this type of business should be closely involved with the local 
community, as they also work to meet the needs of these people (TRAVAGLINI; BANDINI; MANCINONE, 2008).

\section{Final Remarks}

The main contribution of this work is the conceptual model based on seven fundamental points, developed from criteria defined by two of the principal definitions of social businesses, and the development of an instrument to analyze the balance between these criteria.

This study adds to the theoretical and empirical knowledge of social businesses, a theme that requires further studies addressing the definition of these companies. Furthermore, this conceptual model can be used to guide researchers and entrepreneurs seeking new sources to understand this type of business.

The companies also had difficulty balancing their social and economic goals, and there were no homogeneous results regarding the points in the conceptual model. The closest result to 5 in the case of the companies in question was for Stated Social Goal, showing that the companies are involved with their social goals, but when it comes to the other points, both social and economic, their values are not homogeneous.

The result for Limited Profit Distribution is highly heterogeneous and one of the highlights of this study. According to the literature, it is expected that all or at least part of the profits should be allocated to improvements and investments in the social side of the business, which is not always a priority in the case of the companies in question. Furthermore, the low rate of investment in other social actions beyond the social objective of the companies should also be highlighted, as these businesses prioritize social goals.

The study identified that the field of social business is growing and requires greater clarity in terms of its concept and definition. Therefore, this study contributes to the field by organizing the main terms and criteria used to analyze this type of business.

Regarding the theoretical implications, this study can serve as a basis for the construction of scales to measure social businesses based on the fundamental points and the questionnaire. As for the empirical implications, this work could help managers to understand how other social businesses handle their economic and social goals. It could also help them in their self-evaluation as a social business by using the model and instrument proposed in this study.

Concerning the limitations of this study, the limitations regarding the respondents should be highlighted, as they were restricted to managers of social businesses. By including the viewpoints of other sections of the population, it may be possible to obtain complementary results concerning the balance of social and economic goals.

As recommendations for future studies, researchers could apply the questionnaire proposed in this study to a larger number of social businesses and different types of enterprises, expanding the statistical base for comparison. Furthermore, other sectors of the population could be included to compare and contrast the different opinions surrounding the balance between economic and social goals. Another opportunity would be to conduct studies to measure and analyze the impacts of the social goals of social businesses.

Future studies could also conduct a more in-depth investigation of the conflicts facing social businesses in their attempt to balance social and economic goals and whether these cause tensions or dilemmas when it comes to decision-making.

Finally, future studies are required to answer the following question: Can enterprises that call themselves social businesses, but which do not fully meet the criteria for this type of business, actually be considered as social businesses? 


\section{References}

BATTILANA, Julie et al. Harnessing productive tensions in hybrid organizations: The case of work integration social enterprises. Academy of Management Journal, v. 58, n. 6, p. 1658-1685, 2015.

BARKI, Edgard et al. Social entrepreneurship and social business: Retrospective and prospective research. Revista de Administração de Empresas, v. 55, n. 4, p. 380-384, 2015.

BORZAGA, Carlo; DEFOURNY, Jacques (Ed.). The emergence of social enterprise. Psychology Press: Madison, EUA, 2004.

BORZAGA, Carlo; DEPEDRI, Sara; GALERA, Giulia. Interpreting social enterprises. Revista de Administração (São Paulo), v. 47, n. 3, p. 398-409, 2012.

COMINI, Graziela. Negócios Sociais e Inclusivos: um panorama da diversidade conceitual. Ashoka, Mapa de Soluções Innovadores. São Paulo, 2011.

COMINI, Graziella M.; ASSAD, Fernando; FISCHER, Rosa Maria. Social Business in Brazil. International Society for Third Sector Research, p. 1-15, 2012.

COMINI, Graziella; BARKI, Edgard; AGUIAR, Luciana Trindade de. A three-pronged approach to social business: a Brazilian multi-case analysis. Revista de Administração (São Paulo), v. 47, n. 3, p. 385-397, 2012.

COOPER, Donald R.; SCHINDLER, Pamela S. Métodos de Pesquisa em Administração12a Edição. McGraw Hill: Brasil, 2016.

DEES, J. Gregory. Enterprising nonprofits. Harvard Business Review, v. 76, p. 54-69, 1998.

DEFOURNY, Jacques; BORZAGA, Carlo. From third sector to social enterprise. London: Routledge, 2001.

DEFOURNY, Jacques; NYSSENS, Marthe. Social enterprise in Europe: recent trends and developments. Social Enterprise Journal, v. 4, n. 3, p. 202-228, 2008.

DEFOURNY, Jacques; NYSSENS, Marthe. Social enterprise in Europe: At the crossroads of market, public policies and third sector. Policy and society, v. 29, n. 3, p. 231-242, 2010.

DOHERTY, Bob; HAUGH, Helen; LYON, Fergus. Social enterprises as hybrid organizations: A review and research agenda. International Journal of Management Reviews, v. 16, n. 4, p. 417-436, 2014.

FISCHER, Rosa Maria; COMINI, Graziella. Sustainable development: from responsibility to entrepreneurship. Revista de Administração (São Paulo), v. 47, n. 3, p. 363-369, 2012. 
GALERA, Giulia; BORZAGA, Carlo. Social enterprise: An international overview of its conceptual evolution and legal implementation. Social Enterprise Journal, v. 5, n. 3, p. 210$228,2009$.

GRASSL, Wolfgang. Business models of social enterprise: A design approach to hybridity. ACRN Journal of Entrepreneurship Perspectives, v. 1, n. 1, p. 37-60, 2012.

KERLIN, Janelle A. Social enterprise in the United States and Europe: Understanding and learning from the differences. Voluntas: International Journal of Voluntary and Nonprofit Organizations, v. 17, n. 3, p. 246, 2006.

MAIR, Johanna; MARTI, Ignasi. Social entrepreneurship research: A source of explanation, prediction, and delight. Journal of World Business, v. 41, n. 1, p. 36-44, 2006.

PORTER, Michael E.; Advantage Competitive: Creating and Sustaining Superior Performance. NY, Free Press, 1985.

PORTER, M.; KRAMER, M. R. "Creating Shared Value" Harvard Business Review, January, 2011. 2011.

PRAHALAD, Coimbatore Krishna. The Fortune at the Bottom of the Pyramid. Pearson Education: India, 2006.

SHAW, Eleanor; CARTER, Sara. Social entrepreneurship: Theoretical antecedents and empirical analysis of entrepreneurial processes and outcomes. Journal of Small Business and Enterprise Development, v. 14, n. 3, p. 418-434, 2007.

SMITH, Wendy K.; GONIN, Michael; BESHAROV, Marya L. Managing social-business tensions: A review and research agenda for social enterprise. Business Ethics Quarterly, v. 23, n. 3, p. 407-442, 2013.

TRAVAGLINI, C., BANDINI, F., \& MANCINONE, K. Social Enterprise Across Europe: a comparative study on legal frameworks and governance structures. Report, 2008.

YOUNG, Dennis R. Alternative perspectives on social enterprise. Nonprofits and business, p. 21-46, 2009.

YUNUS, Muhammad; MOINGEON, Bertrand; LEHMANN-ORTEGA, Laurence. Building social business models: Lessons from the Grameen experience. Long Range Planning, v. 43, n. 2, p. 308-325, 2010. 